\title{
RESEARCH ON COMPREHENSIVE USING OF PULP OF CORN STALK FERMENTATION RESIDUE
}

\author{
Tingting Li, Tianfu Xue, Mei Yang* \\ Key Laboratory for Biological Fermentation in Jilin Institute of Chemical Technology Chengde Street 45, Jilin, China. \\ *Corresponding Author Email: 91yangmei@163.com
}

This is an open access article distributed under the Creative Commons Attribution License, which permits unrestricted use, distribution, and reproduction in any medium, provided the original work is properly cited

\section{ARTICLE DETAILS}

Article History:

Received 26 June 2018

Accepted 2 july 2018

Available online 1 August 2018

\begin{abstract}
Abundant fermentation residue could be produced in the course of alcoholic fermentation from the pulp of the corn stalk. In order to make good use of the residue, classification using of stalks in the corn stalk fermentation residue was studied in this paper, by determining the content of protein and digestion in vitro of the fermentation residue, the possibility of fermentation residue of stalks in corn stalk for making livestock feeding was validated.
\end{abstract}

\section{KEYWORDS}

The pulp of corn stalk, Fermentation residue, Content of protein, Digestion in vit

\section{INTRODUTION}

Comprehensive utilization of stalks is a very important issue. It not only concerns environmental pollution, but also affects economic efficiency. In this procedure, we must continue to learn new technologies and methods, master advanced technologies at home and abroad, convert the use value of straw, and produce economic benefits while protecting the environment [1].Comprehensive utilization of crop stalks is roughly based on the use of the value of fertilizers from straw and the promotion of its returning technology; Use the fuel value of straw to improve the rural energy environment; use the feed value of straw to develop the breeding industry.

Corn stalk is mainly composed of three parts: skin, pupa and leaf. The corn stalks are relatively hard, the fibers are tight, and the organic content is high; Corn Stover leaves have higher crude fat and protein content, and lower crude fiber conten; Pulp of corn stalk contains a large amount of crude fat, crude protein and carbohydrates [2-9]. The interior of the corn Stover has a mesh-like structure and has good air permeability. This shows that full use of corn stalks resources, the pulp is separated from the corn stalks, and after fermentation, feeds are made by adding corresponding additives according to different feeding objects.

Pulp in corn stalk fermented alcohol will produce a large amount of residue. For the comprehensive utilization of the fermented residue, there are few references in the literature [10]. The fermentation residue after alcoholic fermentation has a soft texture compared with that before fermentation, and it has an aroma of wine and good palatability due to the production of ethanol and organic acids in the fermentation process. For feed, protein, fat, and cellulose are extremely important components. So the higher the protein content in the fermented residue, the better. In this paper, pulp fermentation residue of corn stalk with alcohol was studied $[11,12]$. Firstly, the fermentation residue was graded, then the protein content and in vitro digestibility were measured, and the feasibility of corn stalk exfoliation as livestock feed was discussed.

\section{MATERIALS AND METHODS}

\subsection{Sample}

After the fermentation residue of stalks in corn stalk was dried, the solid fermentation residue was obtained.

\subsection{Equipment and Reagents}

SH220F Graphite dissociator, K9840 Automatic kjeldahl apparatus, Digestive duct, Drying oven, Water bath kettle, Centrifuge,Vacuum drier, Acid burette.Concentrated sulphuric acid,Copper sulfate,Potassium sulfate,Anhydrous Sodium Acetate,Glacial acetic acid,Boric acid - indicator mixture, $10 \mathrm{~mol} / \mathrm{L}$ Sodium hydroxide solution mixed indicator,Standard ammonium sulfate solution (nitrogen $0.3 \mathrm{mg} / \mathrm{mL}$ ) $、 0.0100 \mathrm{~mol} / \mathrm{L}$ Standard solution of hydrochloric acid,Pepsase ( $\geqq 1200 \mathrm{U} / \mathrm{g}$ ) ,Cellulase

$(200000 \mathrm{U} / \mathrm{g})$.All of the reagents were analyzed pure, distilled and diluted with water for deionized water.

\subsection{Experimental method}

\subsubsection{Protein content determination method}

Accurately weighting the fermentation residue of drying by $1 \mathrm{~g}$ (accurate to $0.0001 \mathrm{~g}$ ), Send the sample to the bottom of the dry digestive duct (be careful not to hang the wall), Add $0.2 \mathrm{~g}$ of copper sulfate, $3.0 \mathrm{~g}$ potassium sulfate, and then add $10 \mathrm{ml}$ concentrated sulfuric acid , shake well. Placing the digestive duct on the graphite disintegrator, the first set of 200,30 $\mathrm{min}$, then transferred to a temperature of 380 , modulation heating $90 \mathrm{~min}$ (including 60 min continue to dissolve the sample after turning green), cooling, distillation (cc: anhydrous sodium carbonate).

Accurately absorb $20.00 \mathrm{ml}$ of the digestive juice to the automatic nitrogen fixation apparatus. Turn on the switch of automatic kernel apparatus and the automatic matching titrator. Open the condenser water valve. The $\mathrm{PH}$ electrode on the titrator is inserted into a nitrogen meter to the bottle that accepts the distillate. Select the instrument "preparation procedure", Sample determination method editing, Set the main parameters, The titration starts automatically after the distillation is completed. Save after editing. Before the instrument titration, choose the "cleaning procedure", install the clean air sample duct, clean the instrument 3 time, and the blank value of the instrument is different from $<0.05$.Calculated as follows:

Calculation formula of protein content: $\mathrm{W}=\frac{\left(v_{1}-v_{0}\right) \times c \times 0.014 \times F}{m \times \frac{v_{2}}{100}} \times 100 \%$

In the above formula: $\mathrm{W}$ is the mass fraction of protein; $\mathrm{M}$ is the sample quality, g; 11 is the volume of the standard solution of hydrochloric acid is 
consumed by titration the distillate of the sample $(\mathrm{mL}) ; \mathrm{V} 0 \mathrm{i}$ is the volume of the standard solution of hydrochloric acid is consumed by titration the distillate of blank; This volume is $0 \mathrm{~mL}$ in the experiment; $\mathrm{C}$ is the standard solution concentration of hydrochloric acid, which is $0.0108 \mathrm{~mol} / \mathrm{L}$ in this experiment; 0.014 is the millimeter mass of nitrogen $(\mathrm{g} / \mathrm{mmol}) ; \mathrm{V} 2$ is the volume of sample diluent that is distilled during distillation, which is 20 $\mathrm{mL}$ in this experiment; $\mathrm{F}$ is the protein conversion factor, which is $6.25 \mathrm{in}$ this experiment.

\subsubsection{Determination of in vitro digestibility}

The mixed fermentation residue and the long fiber fermentation residue and the short fiber fermentation residue were respectively used in the prescreening. It was baked in an oven at $105^{\circ} \mathrm{C}$ until the weight is constant, and quality before and after baking was weighed. The dried material was crushed and sieved through a 40 -mesh sieve to obtain samples to be tested.

After washing the digestive duct, it is placed in an oven at $80^{\circ} \mathrm{C}$ to dry it to a constant weight, then it is taken out and put into the desiccator, cooled and weighed. Weighing $0.5 \mathrm{~g}$ sample into the digestive duct to determine the dry matter content of the sample. Then add $50 \mathrm{~mL}$ of protease digestion solution into the digestive duct, and digest it in a 40 water baths for $24 \mathrm{~h}$. Shake 3 4 times during this period. After the end, take out the excretory duct and put it into the 80 -water bath for $30 \mathrm{~min}$.Take out the protease digestion solution and centrifuge it, discard the supernatant. Add $50 \mathrm{~mL}$ of cellulase digestion solution to the residue after centrifugation, and then digest it in a 40 water baths for $24 \mathrm{~h}$.Shake 3 to 4 times during this period, after the end of the digestive duct out and immediately into the 80-water bath pot to digestion are $30 \mathrm{~min}$, remove the centrifuge. Finally, the digestive tube containing the residue is placed in a $105^{\circ} \mathrm{C}$ drying oven and baked until the weight is constant. Calculated as follows:

$$
\mathrm{D}=\frac{\mathrm{m}-m_{0}}{m} \times 100 \%
$$

In the formular: $\mathrm{D}$ is digestibility, $\%$; $\mathrm{m}$ is dry weight of sample in the test tube before digesting , $\mathrm{g} ; \mathrm{m}_{0}$ is the weight of residue in the test tube after digesting

\section{RESULTS AND DISCUSSION}

\subsection{Classification of pulp fermented residue of corn stalk}

Pulp fermentation residue of in corn stalk. was dried after fermentation, and the long and short fiber was divided into two levels after the sieve of 8 mesh screens. Through the sieve is the short fiber fermentation residue, which is left in the sieve is the long fiber fermentation residue. The results of classification are shown in the figure.

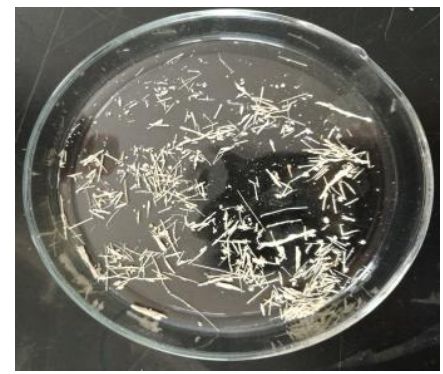

Figure 1: Long fiber fermentation residue

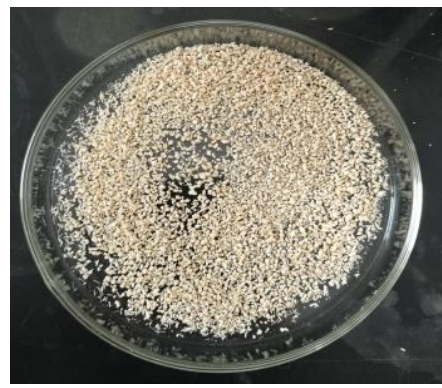

Figure 2: Short fiber fermentation residue

Figure 1, We can see that the long-fiber fermentation residue have long trail. They are loose, they do not stick to each other, and they have a certain degree of toughness. They can be used for raw materials for pulp. Figure 2 , The short-fiber fermented residue is granular. After fermentation, it has a light bouquet, soft texture and good palatability. The ratio of the content of long fibers and short fibers is about 1:5.

\subsection{Determination of protein content in pulp fermentation residue of corn stalk}

The experimental data of protein content determination is shown in table 1.

Table 1: Protein content determination results

\begin{tabular}{|llll|}
\hline & Quality/g & $\begin{array}{l}\text { The volume of } \\
\text { hydrochloric } \\
\text { acid consumed } \\
\text { /mL }\end{array}$ & $\begin{array}{l}\text { The mass } \\
\text { fraction of the } \\
\text { protein/\% }\end{array}$ \\
\hline $\begin{array}{l}\text { Mixed } \\
\text { fermentation } \\
\text { residue before } \\
\text { grading }\end{array}$ & 0.50 & 7.86 & 7.43 \\
$\begin{array}{l}\text { Long fiber } \\
\text { fermentation } \\
\text { residue }\end{array}$ & 0.50 & 4.94 & 4.67 \\
$\begin{array}{l}\text { Short fiber } \\
\text { fermentation } \\
\text { residue. }\end{array}$ & 0.50 & 8.12 & 7.67 \\
\hline
\end{tabular}

You can see from table 1.The protein content of the mixed fermented residue before grading was $7.43 \%$.The protein content of long fiber fermentation residue was $4.67 \%$.The protein content of short fiber fermentation residue was $7.67 \%$.It can be seen from this that the protein content of short fiber fermentation residue is slightly higher than that before grading, while the protein content in the long fiber fermentation residue is much lower than that in the before grading. Therefore, it can be used to feed livestock with the pulp fermentation residue of short fiber stalks in corn stalk, a certain amount of other nutrients can be added when feeding, or direct feeding. In recent years, the straw feed can increase the profit per $\mathrm{h} \mathrm{m}^{2}$ by 500-1500 yuan, the annual output of straw feed increase by $30 \% \sim 40 \%$, it's equivalent to saving about 8 million tons feed grains, the direct economic benefits of 4.5 billion yuan, it's an enticing prospect.

\subsection{Determination of in vitro digestibility of the pulp fermented residue of corn stalk}

The in vitro digestibility results are shown in Table 2.

Table 2: In vitro digestibility results

\begin{tabular}{|c|c|c|c|c|c|}
\hline & $\begin{array}{c}\text { The dry } \\
\text { weight of the } \\
\text { sample } \\
\text { before } \\
\text { digesting/g }\end{array}$ & $\begin{array}{c}\text { The weight } \\
\text { of residue in } \\
\text { the test tube } \\
\text { after } \\
\text { digesting/g }\end{array}$ & $\begin{array}{c}\text { Digestibility/ } \\
\%\end{array}$ & $\begin{array}{c}\text { Average } \\
\text { digestibility/ } \\
\%\end{array}$ & $\begin{array}{c}\text { Corrected } \\
\text { digestibility } \\
\%\end{array}$ \\
\hline $\begin{array}{c}\text { Mixed } \\
\text { fermentation } \\
\text { residue } \\
\text { before } \\
\text { grading }\end{array}$ & $0.500 、 0.500$ & $\begin{array}{l}0.2960 \text { 、 } \\
0.3102\end{array}$ & $40.08 、 37.96$ & 39.02 & 57.78 \\
\hline $\begin{array}{l}\text { Long fiber } \\
\text { fermentation } \\
\text { residue }\end{array}$ & $0.500 、 0.500$ & $\begin{array}{l}0.4315 \text {, } \\
0.4127\end{array}$ & $13.7 、 17.46$ & 15.58 & 39.46 \\
\hline $\begin{array}{l}\text { Short fiber } \\
\text { fermentation } \\
\text { residue }\end{array}$ & $0.500 、 0.500$ & $\begin{array}{l}0.2897 \\
0.2995\end{array}$ & $42.06 、 40.10$ & 41.08 & 59.39 \\
\hline
\end{tabular}

As can be seen from Table 2, In vitro digestibility of ungraded mixed fermentation residue and short fiber fermentation residue was higher. It may be because they contain higher levels of starch, which can be hydrolyzed to sugars that are conducive to digestion and absorption under acidic conditions, so they exhibit higher in vitro digestibility. Because of the high fiber content in long fiber fermentation residue, it is not easy to be degraded into the digestible sugar, so its digestibility is low.

\section{CONCLUSION}

This experiment studied the grading utilization of the pulp fermentation residue of corn stalk, Pulp fermentation residue of corn stalk was divided 
into long fiber fermentation slag and short fiber fermentation slag. By determining the content of protein and digestion in vitro of the fermentation residue, the following conclusions: After pulp fermentation residue of corn stalk are passed through the 8 mesh screen, They are divided into long-fiber fermentation slag and short-fiber fermentation slag. As determined experimentally, Protein quality score of long fiber fermentation residue was $4.67 \%$. They are long strips, they do not stick to each other, are loose, have good toughness and can be used to raw materials of papermaking; Protein quality score of short fiber fermentation residue was 7.67\%.In vitro digestibility was 59.39\%.It's fine grained. The faint smell of wine after fermentation. It has a soft texture and good palatability, which can be used to feed livestock. In this way, the waste of fermented residue after fermentation is fully utilized, make it wasteful. This has great significance for improving the utilization of resources and protecting the environment and increasing farmers' income. The prospect is very attractive.

\section{REFERENCE}

[1] Li, L., Xing, Y. 2016. Comprehensive utilization of crop straw and protection of ecological environment [J]. Examination Weekly, 6 (2), 196.

[2] Thompson, D.L. 1963. Stalk Strength of Corn as Measured by Crushing Strength and Rind Thickness [J]. Crop Science, 3 (4), 323-329.

[3] Li, Y., Qin, T., Chen, J. 2011. Test and analysis of the mechanical properties of corn stalk reciprocating cutting [J]. Transactions of the CSAE, 27 (1), 160-140.

[4] Li, H. 2014. Evaluation of nutritional value of corn stalk and its fermentation feed [D]. Harbin: Northeast Agricultural University.

[5] Xie, T., Cao, W., Shi, Y. 2010. The present situation of corn stalk feed and the application of corn straw pulp pellet feed [J]. Agriculture and Technology, 30 (1), 66-68.

[6] Phutela, U.G., Kaur, J. 2014. Process optimization for ethanol production from sweet sorghum juice using saccharomyces cerevisiae strain NRRL Y-2034 by response surface methodology [J]. Sugar Tech, 16 (4), 411-421.

[7] Yesuf, J.N., Liang, Y. 2014. Optimization of sugar release from sweet sorghum bagasse following solvation of cellulose and enzymatic hydrolysis using response surface methodology [J]. Biotechnology Progress, 30 (2), 367-375.

[8] Miller, G.L. 1993. Use of dinitrosalicylic acid reagent for determination of reducing sugar [J]. Anal. Chem., 31, 426-428.

[9] Zeng, X., Ma, Y., Ma, L. 2007. Utilization of straw in biomass energy in China [J]. Renewable and Sustainable Energy Reviews, 11, 976-987.

[10] Wang, X., He, C., Li, G. 2015. Characteristics of Anaerobic Fermentation with Different Parts of Corn Stalks at Low Concentrations [J]. International Journal of Green Energy, 12 (10), 1018-1024.

[11] Msarah, M., Alsier, A. 2018. Protein Digestibility and Amino Acid Content of Malaysian Local Egg Pro tein Prepared by Different Methods. Environment and Ecosystem Science, 2 (1), 07-09.

[12] Ghosh, S., Das, A.P. 2017. Bioleaching of manganese from mining waste residues using Acinetobacter sp. Geology, Ecology, and Landscapes, $1(2), 77-83$ 